Mrs. RoBB.-That is one of the details that I think should be settled hy the central committee. Of course, this paper is simply the first thoughts; there are many still to be added; it was impossible in twenty minutes or half-hour's paper to more than suggest, hut it is a subject, I think, which really calls for several more papers before we will have a comprehensive understanding of it. The suhject of finances is one which naturally helongs to the central committee, but I will say that in suggesting and making up the committee I purposely put on the central committee representation from the trustees of the hospital because they are the ones, I think, who should assume the financial responsibility.

Mrss MAXweLL.-Dr. S. Weir Mitchell says that if we are to make nursing a profession we will have to put it on educational lines, and in order to put it on educational lines we must charge for admission to our training-schools and make all pay for what they get.

Mrs. RoBs.-Of course, the object in presenting this paper to-day is not only hecause the suhject very closely affects the superintendents' work, hut because I feel that if you think there is anything worth considering in it, it is necessary that some steps should be taken, such as a committee appointed.

Mrss NuTriva.-Could there be any better time in which to appoint a committee than when the two societies are gathered together to confer and the result of the combined wisdom can he ohtained. The suggestion has already heen made that some steps should follow.

Mrss McMilian.- I move that the president be authorized to appoint a committe to take up this matter.

Seconded hy Miss Maxwell. Carried.

Mrss Nutrisa.-There seems to be nothing further to add to this discussion, so we will proceed at once as rapidly as possihle to the business part of our meeting, which will he brief. Being at once chairman and acting secretary of this society, it devolves upon me to read a short paper which Miss Dock would present if she were here. When the question arose last fall of the affiliation of this hody with the International Council of Nurses a letter was written from that body and sent here; it was placed in The AMErions Joursic or NuRsina, and it was also sent to every member of the councils of the two societies. The councillors have done what was possihle to do, hut realizing that the opportunity for a meeting together here to-day was a very unusual one, we took advantage of it in order that every graduate present might have, the privilege of recording her own vote for whatever form the continuation of this society might take and for its relationship with the societies of other countries. Before doing anything in a business way, it was deemed better to give a very hrief history of international relationships in order that you may all know exactly what the American Federation of. Nurses is and what it means.

\title{
INTERNATIONAL RELATIONSHIPS
}

\author{
BY L. L. DOCK \\ Honorary Secretary International Council of Nurses
}

"It is now five years since the Congress in London took place, at which time the first suggestions for an international union of trained nurses were made to the nurses there present. For the benefit of any to-day present who may not have followed all the incidents and reports, 
I may very briefly run over the most important details and show where we stand to-day as to international relationships and what, so far as we can see, are the prospects before us.

"The group of American nurses who went to the London Congress all went, as it were, hap-hazard, either because they happened to be in England or because they were personally interested and curious to see what a great congress of women would be like. The Nursing Section, which had been made a part of the programme at Mrs. Fenwick's instance, was something quite new in women's gatherings, had attracted little or no attention in our American organizations, none of which had official delegates there to represent them, and had a somewhat informal programme. Nevertheless, it was of so much interest and was to the nurses present so stimulating, that-the spirit of organization being in the air of the great gatherings of women-the suggestion, first made by Mrs. May Wright Sewall, that nurses also organize internationally, was received with enthusiasm. A Provisional Committee was formed to draft a constitution, and this constitution was sent around and was accepted, and the members of the Provisional Committee, with others whom they called upon to aid them, became for the time being the International Council of Nurses. The idea, of course, was that the council should eventually be composed of national societies, each society representing one country, but the fact that at that moment no country but our own was well organized did not discourage the individual members, for they believed that the formation of an international council might help to stimulate organization in other lands. We had in America our two societies, the Superintendents' and the Alumnæ, and, in order to be able to consider them as one, Mrs. Sewall, who is a genius at organization, suggested that we affiliate them under the simplest possible form, so as to leave each one quite as it was, only making it possible for them to be regarded as one and to act as one for such special purposes as might seem desirable, the main purpose being to have one representative body ready to unite in friendly relations with national societies in other countries.

"In order to have the privileges of membership in the great congresses of women meeting every five years, and which are formed by the National Councils of Women of each country, we joined the National Council of Women of the United States, entering it as the American Federation of Nurses, which we created quite informally, without a written constitution and almost without rules, simply by the adopted motions of the Superintendents' and Alumnæ Associations, to the effect that they would unite in paying the dues to the Council of Women, and would each appoint two members, and that these four members should 
choose a fifth, who should act as the chairman and president of the Federation of Nurses. In this simple fashion we have carried it on since then without any trouble, and as the whole international situation was hardly in the budding stage-one might say only a seedling-it has answered so far very well.

"But the time has now come-or will soon come-when we shall possibly find it easier to progress if we have a rather more definite form. "The London Congress was held in 1899, and in 1901, still only consisting of individual members, the International Council of Nurses suggested a Congress of Nurses at Buffalo, which you all remember and which was a really great event in the nursing world. The Berlin Congress of Women last year gave the subject of nursing education a position of prominence, the largest assembly hall being devoted to the subject during one day's session, while a second smaller hall held a session upon district nursing and related subjects. This interest was largely due to the acute circumstances in German nursing, which have induced the German National Council of Women to take up the support of the modern nursing movement with great earnestness. However, the German conditions did not monopolize the field, but most generous opportunity was given, especially to the English and American nurses, to describe their conditions and to give their reasons for supporting the principles of a broader education for nurses.

"As to nursing organization, we had also our own separate day and place in Berlin, where the formal proceedings of the International Council of Nurses (still consisting only of individuals) were conducted under its constitution. We learned there that England, since the Buffalo Congress, had been organizing nurses with great energy on lines similar to our alumnæ associations (called in England leagues), and that these leagues had formed a Provisional Committee, looking forward to the definite formation of a national society and affiliation with the International Council. We also found that Germany, quite independently of outside influence (for they had heretofore known nothing of foreign nursing organizations), and entirely as the result of irresistible modern conditions, had formed a national association called the German Nurses' Association, now consisting of orer six hundred members and growing daily, which is entirely self-governing, organized and conducted exactly like our own, and having the same purposes and ideals.

"At the Berlin meeting formal invitations were given to the English and German associations to join the International Council, and both have accepted. At the next regular meeting in Canada in 1809 we shall have official delegates from these societies, and, we hope, from the American Federation. The question of suitable and not too burdensome dues 
will then be discussed and settled as an amendment to our present international constitution, and plans for an international campaign for the great general movement towards self-development, broader education, and progressive ethics will be outlined. I feel that some account of the difficulties of our foreign sisters might be in place here for the benefit of those who have not given much attention to the subject, yet to try to enter into details would exhaust your time and might also give very erroneous impressions. I will only remind you, therefore, that whereas we in America have only an educational problem,- that is, a singlefaced problem, - the pioneers of modern nursing in Europe have a fourfold opposition to overcome.

"First, the religious prejudice.

"It has been and will long continue to be a bitter struggle to secure the right of nursing to be 'unconfessional' or independent of religious orders. And let it not be overlooked that this is not alone a lofty spiritual domination. It has a solid financial basis in that all orders control entirely the earnings of their nurses.

"Second, social prejudice.

"The class distinctions which have existed in most European countries have worked serious detriment to the growth of ideas necessary for the progress of nurses, and have hampered and do still hamper forward movements. The more rigid these distinctions, the more injurious is the prejudice.

"Definite unfavorable results of social prejudice that may be mentioned in a general way are: (1) the long established usage in many places of having two distinct classes of nurses-one a higher grade, monopolizing positions of authority by virtue of their class; one a lower grade, largely recruited from the peasants and domestic servant ranks, doing the hardest work, being accorded no respect, and existing as a dead weight in the educational problem and in the movement towards self-government; (2) a feeling of contempt, not for work as such, but for work done for money, and especially for nursing work followed as a means of livelihood. This, with its concomitant of patronage and benevolence, has made the struggle of the individual towards self-respecting independence doubly hard.

"Third, masculine prejudice.

"It is unnecessary to dilate upon this point. I would only like to say that in no country of the world, unless perhaps New Zealand and Australia, are men in general so fair to women, and the medical professional in particular so generous and so brotherly towards nurses, as in America.

"While you may all think you know some exceptions or have some 
grievances, I can assure you they are insignificant. I have made many scientific investigations upon this subject, and have collected much valuable data.

"Fourth, industrial prejudice.

"This is, of all, in many countries, the easiest to overcome, yet it also has not a few difficulties, and these are now especially striking in England. You are all familiar with the situation there, but may not all realize that at bottom it is largely an industrial prejudice, I might say, industrial superstition, that is opposing State registration. This, to my mind, is made clear by an editorial in the Lancet of January 7, 1905 , which speaks of the nurses' bills as containing the objectionable feature of 'Labor with a capital $L$;' says that any proposition to register nurses which carries with it the semblance of a trade-union must be doomed to fail, and speaks of "the fear that the registration movement might be used to safeguard the interests of the employed against the employer.'

"If these words mean anything, they mean that there is a sordid fear of allowing nurses to work for reforms through their own associations.

"Meantime, the organized nurses of Great Britain and Ireland, of whom there are now many hundreds, are carrying forward a campaign of education with intelligence, courage, and determination, such as must command our respect and deepest sympathy.

"Thus these four lions lie in the path of our over-sea sisters. In one country one will be found more prominent, in another, another, but in every country they are all present to some extent and in varying proportions. In the next five years among Continental countries it is likely that Germany and France will make the most progress. The whole drift of tendencies shows it, and in Germany, in Sister Agnes Karll the new movement has a leader of rare qualities, who has the genius of winning friends and of making converts.

"In France, as many of you know, a most dramatic movement is going on. The city government of Paris, with the best intentions in the world but with little practical knowledge, has for years been trying to educate wholesale a modern nursing staff. Three or four years ago the hospital department of Paris applied to the Charity Organization Society of New York City for printed material relating to training-school organization in America, and the writer collected this material for the society, including many of your prospectuses, study courses, rules, working plans, printed reports, Superintendents' Society and Alumnæ Reports, etc., etc., all of which was sent to them. They have also studied the nursing system of England, and this especially with renewed zeal 
and admiration in the last year or two. . Through the work of Dr. Anna Hamilton in Bordeaux and Madame Alphen-Salvador in Paris they now have object-lessons of what a nursing staff ought to be and how it ought to be trained. They now realize that they need the help of women with authority, and in the past year an English nurse, Miss Wortabet, has been called to coöperate with the Paris officials in reorganization work.

"In Italy a Johns Hopkins nurse, Miss Baxter, has worked for nine years under great difficulties, and has succeeded in making a success of the first regular training-school in Italy. She now has thirtyfive graduatcs, educated women trained in modern methods, and Miss Turton and Signora Celli, of whom you may have read in the Joursal, are also continuous in efforts towards reforms.

"In Holland there are two associations, one rather conservative, composed of nurses, physicians, and hospital Governing Boards (admired of our friend, Dr. Worcester) and a national association of nurses. The latter society, which also numbers among its members some of the more radical physicians, who are outspoken in advocating a higher educational standard for women, is in sympathy with the ideals of the International Council of Nurses, and is ready for membership. There is also a Matrons' Council in Holland, corresponding to our Superintendents' Society. Educational questions are much to the fore in Holland.

"In Denmark there is a national association of nurses quite conservatively managed. So far it has taken no notice of international movements and seems not to have any special problems. Denmark seems a happy little country where everyone is well off and with nothing much to worry them.

" (These little pictures of mine are naturally to be taken as sketches, and not as photographs.)

"I have not spoken of Australia and New Zealand because their conditions are not greatly different from our own. They are in some respects more advanced than we, and are well fitted to act as counsellors and friends to the pioneers of new movements of older lands.

"Now if it is asked, 'What advantage from international organization?' one must answer, it is probably true that the great rank and file will never be directly conscious of direct benefit. But the leaders, who are working for the rank and file, will realize the benefits to the full, and do so already. In every country there is a little group, sometimes of two or three, sometimes only one, who are carrying the whole burden. To these international union will be an inestimable help. Simply the consciousness of being understood and sympathized with is an encourage- 
ment, and the knowledge of not struggling alone, but that others are making the same efforts, gives renewed strength.

"As to whether we can carry membership in an international association of our own and also in the National Council of Women is a question. It must be admitted that the National Council of Women in the United States is not as effective and purposeful an organization as those of other countries. I am also surprised to find how disproportionately high are its dues.

"The German Nurses' Association pays five dollars yearly for membership in the German National Council of Women. The English dues are about the same. Ours are more than six times as much. True, everything in America costs more, but not six times more.

"It is also true that the National Council of Women makes many demands upon the time and strength of our officers which these busy women are not able to meet. Neither do these demands seem to be of as much definite importance as their own nursing work.

"Time has not shown that we are of any real usefulness in the National Council of Women, whereas we can be definitely helpful and useful in an international union of our own colleagues. Personally I feel that this membership has been of great benefit to us in enabling us to come into relation with nurses of other countries, and in giving us a status in the great Congresses of Women. If we could do everything, I would gladly see our membership continued just for this reason. But the impossibility of doing everything compels a choice sometimes, and if one has to be made, I feel that our nurses' international association is much more important.

"I might mention now that an informal meeting of the International Council of Nurses in Paris in the summer of 1907 is under consideration, not for business or regular transactions, as such can only occur every five years according to our constitution, but for conferences, papers, and discussion. It is thought that an interims gathering would be of great interest and benefit, and that the cost of a meeting-place could be defrayed by admission fee, with, perhaps, some small contributions from benevolent nursing associations. So, brush up your French and lay your plans.

"And now my best wishes for the results of your conferences."

Mrss Nutriva.-We have, then, first to consider the invitation of the International Council of Nurses to the American Federation of Nurses to affiliate with that body. This invitation, already expressed through the pages of your JounNAL and already sent to the members individually of both societies, is now before you. 
Miss Drown.-I move, first, that the American Federation of Nurses withdraw its membership in the National Council of Women of the United States.

Seconded by Miss Giles and Miss Maxwell and carried.

Miss Nutriva.-The next question is the one which was brought up $n$ moment ago, and that is the acceptance of the invitation of the International Council of Nurses to the American Federation of Nurses to affiliate with that body.

Miss SamueL.-I move that the American Federation of Nurses accept the invitation to afliliate with the International Council of Nurses.

Seconded by Mrs. Quintard and carried.

Miss Nutrina.-There is one other matter, and that is the fact already referred to that we have had no form of government, and that a loosely organized thing is very liable to fall to pieces if there is not something to bind it together. Therefore, those who have been considering the matter felt that the very simplest and briefest form of a constitution should be adopted by the Federation, and such a form of constitution has been drawn up to present to you to-day. The question is; shall it be presented ${ }^{\circ}$

Mrss McIsasc.-I move that the constitution as prepared be presented to the society.

Seconded by Miss Goodrich.

Miss Nutting read the constitution as prepared.

\section{PROPOSED CONSTITUTION FOR THE AMERICAN FEDERA- TION OF NURSES} Nurses.

"I. The name of this body shall be the "American Federation of

"II. Its purpose shall be to enter into organized relations with national councils or associations of nurses in other countries.

"III. Its officers shall be the active officers of the American Society of Superintendents of Training-Schools for Nurses, and of the Nurses' Associated Alumnæ, and of any other affiliated association. They shall choose their own chairman, to be known as president of the American Federation of Nurses, a secretary, and a treasurer, and shall appoint such committees and sub-committees as are necessary.

"IV. The duties of officers shall be to do all that is necessary in maintaining and developing organized relations with nurses of other countries, and to act upon all matters referred to the Federation by the affiliating societies.

"V. The fees of each affiliating society shall be fifteen dollars a year, payable on September 1."

Mrss McIsaAc.-I move that the constitution be accepted as read.

- Seconded by Miss Goodrich and carried.

Mrs. RosB.-I want to say just one more word in regard to my paper. I may not be broad-minded enough, but it did seem to me that when I was preparing my paper that it properly belonged to the Society of Superintendents, because while we all are interested as a profession in the results of affiliation, 